\title{
Impact of Government Borrowing on Bank Liquidity Crisis: An Econometric Analysis
}

\author{
Raad Mozib Lalon \\ Department of Banking and Insurance, University of Dhaka, Dhaka, Bangladesh
}

Email address:

lalon.banking@gmail.com

\section{To cite this article:}

Raad Mozib Lalon. Impact of Government Borrowing on Bank Liquidity Crisis: An Econometric Analysis. International Journal of Economics, Finance and Management Sciences. Vol. 3, No. 5, 2015, pp. 526-534. doi: 10.11648/j.ijefm.20150305.23

\begin{abstract}
This paper attempts to reveal the ultimate determinants affecting the recent liquidity position of commercial banks in Bangladesh. The whole scenario is presented through focusing on the various elements affecting the liquidity position in commercial banks over a period of time. This liquidity position of commercial banks is affected by many macro economic variables such as savings and investment, distribution of credit, interest rates and economic growth. The models developed in this paper divulge that some of the determinants such as share price Index, overall investment position of commercial banks, $\mathrm{M}_{2}$ Currency, overall classified loans of commercial banks and outstanding amount of L/C significantly affect the liquidity position of commercial banks in Bangladesh. Although net government borrowing from banking sector also affects the liquidity position of commercial banks through creating crowding-out effect for private investors, the models mentioned in this study reveal that net government borrowing is not individually significant in explaining liquidity position of commercial banks rather this net government borrowing along with other variables is jointly significant in explaining liquidity position. As a corollary, this paper examines whether the so-called Government borrowing in recent years may cause the liquidity crisis in commercial banks of Bangladesh.
\end{abstract}

Keywords: Liquidity Position (LP), Investment (INV), Classified Loan (CL),

Outstanding Amount of Letter of Credit (OULC), Net Government Borrowing (NGB),

Cash Reserve Ratio (CRR), $\mathrm{M}_{2}$, Rescheduling, Loan Against Trust Receipt (LTR)

\section{Introduction}

A liquid financial firm either has the right amount of immediately spendable funds on hand when they are required or can raise liquid funds in timely fashion by borrowing or selling assets. The main sources of funds of commercial banks are deposits (Liability of banks) that are applied (used) to provide credit to different clients in business \& industry (borrowers) as advances (assets of banks). So bank deposits and credits have important responsibility on liquidity position which can be regulated through asset and liability management of a bank. Banks can exert indirect influence on deposits and advances through regulating interest rates (deposit \& lending rate). The task of regulating the liquidity position of commercial banks depends on the degree of sensitivity of deposits and advances to interest rate. The government and the monetary authority can influence directly the overall liquidity scenario in commercial banks. In Bangladesh the totality of liquidity is indicated by what is called "broad money". A shortage of money restricts demand by making it more difficult to engage in transactions. This study analyzes the major reasons that depict why the shortage of broad money has been occurred in the recent money market of Bangladesh.

\section{Literature Review}

According to Aspachs et al. (2005), there are some mechanisms that banks can use to insure against liquidity crises: banks hold buffer of liquid assets on the asset side of the balance sheet. A large enough buffer of assets such as cash, balances with central banks and other banks, debt securities issued by governments and similar securities or reverse repo trades reduce the probability that liquidity demands threaten the viability of the bank.

The second strategy is connected with the liability side of the balance sheet. Banks can rely on the interbank market where they borrow from other banks in case of liquidity demand. However, this strategy is strongly linked with 
market liquidity risk.

The last strategy concerns the liability side of the balance sheet, as well. The central bank typically acts as a Lender of Last Resort to provide emergency liquidity assistance to particular illiquid institutions and to provide aggregate liquidity in case of a system-wide shortage.

Bank-specific and macroeconomic determinants of liquidity of English banks were studied by Valla and SaesEscorbiac (2006). They assumed that the liquidity ratio as a measure of the liquidity should be dependent on following factors (estimated influence on bank liquidity in parenthesis): probability of obtaining the support from lender of last resort, which should lower the incentive for holding liquid assets (-), interest margin as a measure of opportunity costs of holding liquid assets (-), bank profitability, which is according to finance theory negatively correlated with liquidity (-), loan growth, where higher loan growth signals increase in illiquid assets (-), size of the bank (?), gross domestic product growth as an indicator of business cycle (-), short term interest rate, which should capture the monetary policy effect (-).

Determinants of liquidity risk of banks from emerging economies with panel data regression analysis are analyzed by Bunda and Desquilbet (2008). The liquidity ratio as a measure of bank's liquidity assumed to be dependent on individual behaviour of banks, their market and macroeconomic environment and the exchange rate regime, i.e. on following factors:

Total assets as a measure of the size of the bank (-), the ratio of equity to assets as a measure of capital adequacy $(+)$, the presence of prudential regulation, which means the obligation for banks to be liquid enough $(+)$, the lending interest rate as a measure of lending profitability (-), the share of public expenditures on gross domestic product as a measure of supply of relatively liquid assets $(+)$, the rate of inflation, which increases the vulnerability of banks to nominal values of loans provided to customers (+), the realization of a financial crisis, which could be caused by poor bank liquidity (-), the exchange rate regime, where banks in countries with extreme regimes (the independently floating exchange rate regime and hard pegs) were more liquid than in countries with intermediate regimes.

The empirical analysis of the hypothesis that interest rates affect banks' risk taking and the decision to hold liquidity across European countries has been proved by Lucchetta (2007). The liquidity measured by different liquidity ratios should be influenced by: behavior of the bank on the interbank market - the more liquid the bank is the more it lends in the interbank market $(+)$, interbank rate as a measure of incentives of banks to hold liquidity $(+)$, monetary policy interest rate as a measure of banks ability to provide loans to customers (-), share of loans on total assets and share of loan loss provisions on net interest revenues, both as a measure of risk-taking behavior of the bank, where liquid banks should reduce the risk-taking behavior(-).

The effects of the financial crisis on the liquidity of commercial banks in Latin America and Caribbean countries investigated Moore (2010). According to him, Liquidity should depend on: cash requirements of customers, captured by fluctuations in the cash-to-deposit ratio (-), current macroeconomic situation, where a cyclical downturn should lower banks' expected transactions demand for money and therefore lead to decreased liquidity $(+)$, money market interest rate as a measure of opportunity costs of holding liquidity (-).

Liquidity created by Germany's state-owned savings banks and its determinants has been analyzed by Rauch et al. (2010). According to this study, following factors can determine bank liquidity: monetary policy interest rate, where tightening monetary policy reduces bank liquidity (-), level of unemployment, which is connected with demand for loans (-), savings quota $(+)$, level of liquidity in previous period $(+)$, size of the bank measured by total number of bank customers (-), bank profitability (-).

Entirely unique is the approach of Fielding (2005). He considered these determinants of liquidity: level of economic output $(+)$, discount rate $(+)$, reserve requirements (?), cashto-deposit ratio $(-)$, rate of depreciation of the black market exchange rate $(+)$, impact of economic reform (-), violent political incidence $(+)$.

Studies cited above suggest that commercial banks' liquidity is determined both by bank specific factors (such as size of the bank, profitability, capital adequacy and factors describing risk position of the bank) as well as macroeconomic factors (such as different types of interest rates, interest margin or indicators of economic environment). It can be useful to take into account some other influences, such as the realization of financial crisis, changes in regulation or political incidents.

\section{Objective}

The fundamental objective of this paper is to decide whether the so called government borrowing can be a major determinant of adjusting liquidity position of commercial banks in Bangladesh.

\section{Methodology}

The study deals with formulating econometric models used to examine whether so called Government Borrowing (GB) can be a major determinant in accelerating the liquidity crisis in commercial banks of Bangladesh. The complete methodology for preparing this paper is revealed below:

\subsection{Research Type}

This is a descriptive research which is relevant to an inquisitive study as it requires some analysis on the reasons accelerating recent liquidity crisis in commercial banks of Bangladesh. It also includes the detailed analysis of econometric models used to reveal whether government borrowing may significantly affect the recent liquidity crisis in commercial banks of Bangladesh. In another part, this paper reveals the methods taken by Central Bank as well as commercial banks and other respective authorities to combat 
against this severe liquidity crisis in commercial banks of Bangladesh.

\subsection{Types of Data}

Preparing this study requires the use of only secondary data related to numerical value of economic variables such as gross domestic product, net government borrowing (GB), liquidity position (LP), classified loans (CL), outstanding amount of L/C (OULC), DSE general share price index (DSI), overall investment of commercial banks (INV) etc collected from both online and documentary sources as depicted below:

\subsection{Data Analysis Tools}

The following Econometric models are used to analyze the effect of economic variables such as gross domestic product, net government borrowing (GB), liquidity position (LP), classified loans (CL), outstanding amount of L/C (OULC), DSE general share price index (DSI), overall investment of commercial banks (INV) on liquidity position(LP) of commercial banks of Bangladesh as depicted below:

- Model 01: $\mathrm{LP}=\mathrm{a}_{\mathrm{o}}+\gamma_{1}(\mathrm{SPI})+\gamma_{2}(\mathrm{NGB})+\gamma_{3}(\mathrm{OULC})+\mu$

Where,

$\mathrm{SPI}=$ General share Price Index

$\mathrm{NGB}=$ Net Government Borrowing

OULC $=$ Outstanding amount of $\mathrm{L} / \mathrm{C}$

$\gamma_{1}=$ coefficient of General share Price Index (SPI)

$\gamma_{2}=$ coefficient of Net Government Borrowing (NGB)

$\gamma_{3}=$ coefficient of Outstanding amount of L/C (OULC)

$\mu=$ standard error of estimate

- Model 02: $\mathrm{LP}=\mathrm{a}_{0}+\gamma_{1}(\mathrm{SPI})+\gamma_{2}(\mathrm{NGB})+\gamma_{3}(\mathrm{INV})+\mu$

Where,

$\mathrm{SPI}=$ General share Price Index

$\mathrm{NGB}=$ Net Government Borrowing

$\mathrm{INV}=$ Overall Investment of Commercial Banks $\gamma_{1}, \gamma_{2}, \gamma_{3}$ are coefficients of SPI, NGB and INV respectively $\mu=$ standard error of estimate

- Model 03: $\mathrm{LP}=\mathrm{a}_{\mathrm{o}}+\gamma_{1}(\mathrm{OULC})+\gamma_{2}(\mathrm{NGB})+\gamma_{3}(\mathrm{CL})+\mu$

Where,

$\mathrm{CL}=$ Classified Loans

$\gamma_{1}, \gamma_{2}, \gamma_{3}$ are coefficients of OULC, NGB and CL respectively

$\mu=$ standard error of estimate

- Model 04: $\mathrm{LP}=\mathrm{a}_{\mathrm{o}}+\gamma_{1}(\mathrm{NGB})+\gamma_{2}(\mathrm{OULC})+\gamma_{3}\left(\mathrm{M}_{2}\right)+\mu$

Where,

$\mathrm{M}_{2}=$ Broad Money; $\gamma_{1}, \gamma_{2}, \gamma_{3}$ are coefficients of OULC, NGB and CL respectively. $\mu=$ standard error of estimate

\section{Liquidity Position of Scheduled Banks}

Central Bank controls the liquidity position in the economy by the cash reserve ratio (CRR) and statutory liquidity ratio (SLR). In the recent monetary policy, central bank has increased the CRR and SLR ratio. Increase of excessive investments in the unproductive sectors such as consumer products and luxurious goods, real estate, and the capital markets etc. creates the stress on liquidity. In this situation, central bank is supplying liquidity help by REPO. As of June 2010, the total liquid assets of the schedule banks were Tk. 87196.61 crore. By the end of June 2011, this went up by Tk. 100564.96 crore. Currently, the amount of required liquidity SLR is BDT 66493.75 crore. The excess liquidity of the schedule banks decreased by Tk. 34071.21 core in June 2011 against BDT 34498.73 crore in June 2010 that means it decreased by 1.23 percent in 2011. Banks hold cash in tills and the excess cash reserves with the $\mathrm{BB}$ (which is around 10 percent of total liquidity) to meet immediate cash withdrawal needs of customers. Balance with Bangladesh Bank and unencumbered approved securities that are 6.58, 36.10 and 57.32 percent of the total liquidity assets.

Table 1. Liquidity position of Money Market in Bangladesh.

(Tk. In crore)

\begin{tabular}{|c|c|c|c|c|c|c|c|}
\hline \multirow[b]{2}{*}{ Bank Group } & \multicolumn{2}{|l|}{ As of end June, 2011} & \multicolumn{5}{|c|}{ As of end Feburary, 2012P } \\
\hline & Total Liquid Asserts & $\begin{array}{l}\text { Required } \\
\text { Liquidity (SLR) }\end{array}$ & $\begin{array}{l}\text { Cash in tills + } \\
\text { balances with } \\
\text { Sonali Bank }\end{array}$ & $\begin{array}{l}\text { Balances with } \\
\text { Bangladesh } \\
\text { Bank }\end{array}$ & $\begin{array}{l}\text { Unencumbered } \\
\text { approved } \\
\text { securities }\end{array}$ & $\begin{array}{l}\text { Total Liquid } \\
\text { Asserts }\end{array}$ & $\begin{array}{l}\text { Required } \\
\text { Liquidity (SLR) }\end{array}$ \\
\hline 1 & 2 & 3 & 4 & 5 & 6 & $7=(4+5+6)$ & 8 \\
\hline State owned Banks & 30146.85 & 19228.08 & 1199.13 & 7316.21 & 26260.90 & 34776.24 & 21557.42 \\
\hline $\begin{array}{l}\text { Private Banks } \\
\text { (Other than } \\
\text { Islamic) }\end{array}$ & 47857.65 & 34591.75 & 3474.95 & 14568.89 & 36254.42 & 54298.26 & 37889.78 \\
\hline $\begin{array}{l}\text { Private Banks } \\
\text { (Islamic) }\end{array}$ & 13418.07 & 6386.33 & 1010.77 & 6532.06 & 3040.48 & 10583.31 & 8532.83 \\
\hline Foreign Banks & 7969.63 & 5273.29 & 447.23 & 4945.56 & 4284.15 & 9676.94 & 5579.85 \\
\hline Special Banks* & 1172.76 & 1014.30 & 222.80 & 1370.34 & 928.60 & 2521.74 & 2149.73 \\
\hline Total & 100564.96 & 66493.75 & $6354.88(+5.68)$ & $\begin{array}{l}34733.06 \\
(+31.05)\end{array}$ & $\begin{array}{l}70768.55 \\
(+63.27)\end{array}$ & 111856.49 & 75709.61 \\
\hline
\end{tabular}

Source:Department of Office Supervision

Total liquid assets of the scheduled banks stand higher at Tk.111856.49 crore as of end February, 2012 against Tk.100564.96 crore as of end June, 2011. Required liquidity of the scheduled banks also stands higher at Tk.75709.61 crore as of end February, 2012 against Tk.66493.75 crore as of end June, 2011, Scheduled banks holding of liquid assets as of end February, 2012 in the form of cash in tills \& balances with Sonali bank, balances with Bangladesh Bank 
and unencumbered approved securities are 5.68 percent,

assets. 31.05 percent and 63.27 percent respectively of total liquid

Total liquid assets \& required liqidity

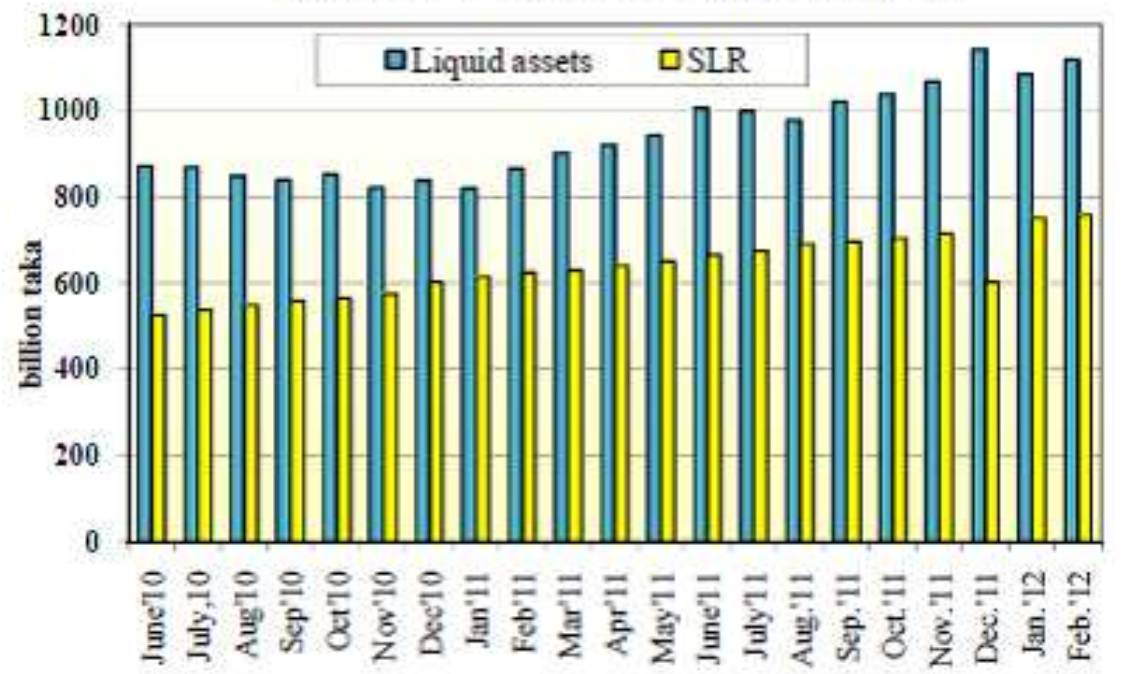

Source (chart: 01): Department of offsite supervision, Bangladesh Bank

Chart 1. Total Liquid assets and required liquidity.

\section{Econometric Modeling}

The following Econometric models are developed to analyze the degree of effect of each of the economic variables such as Gross Domestic product, Net Government Borrowing (GB), Liquidity position (LP), Classified Loans
(CL), Outstanding amount of L/C (OULC), DSE General share Price Index (DSI), Overall Investment of Commercial Banks (INV) on Liquidity Position (LP) of commercial banks of Bangladesh:

Table 2. Variables used in Modeling.

\begin{tabular}{lll}
\hline Variables & Explanation & Type of Variables \\
\hline LP & Overall Liquidity position of Commercial Banks & Dependent \\
SPI & DSE General share Price Index & Independent \\
M2 & M1+Time Deposit & Independent \\
OULC & Outstanding L/C Position of Commercial Banks & Independent \\
CL & Overall Classified Loan in Commercial Banks & Independent \\
INV & Overall Investment of Commercial Banks & Independent \\
NGB & Net Government Borrowing from Banking Sector & Independent \\
\hline
\end{tabular}

Model 01: $\mathrm{LP}=\mathrm{a}_{\mathrm{o}}+\gamma_{1}(\mathrm{SPI})+\gamma_{2}(\mathrm{NGB})+\gamma_{3}(\mathrm{OULC})+\mu$

The results along with explanation of this model are summarized below:

Table 3. Statistical Result of the model.

\begin{tabular}{|c|c|c|c|c|}
\hline Coefficients (Standerdized) & 21.609 & 1.435 & -1.267 & .874 \\
\hline S.E & .798 & .000 & .000 & .007 \\
\hline t-value & 27.085 & 4.385 & -3.443 & 3.874 \\
\hline p-value & 0.000 & 0.022 & 0.041 & 0.030 \\
\hline $\mathrm{R}$ & 0.949 & \multirow{2}{*}{\multicolumn{3}{|c|}{$\begin{array}{l}\text { High degree of positive relationship } \\
90.1 \% \text { of variability in Liquidity Position is explained by all explanatory (independent) variables }\end{array}$}} \\
\hline $\mathrm{R} 2$ & .901 & & & \\
\hline Adjusted R2 & .803 & \multicolumn{3}{|c|}{$90.1 \%$ of variability in Liquidity Position is explained by all explanatory (independent) variables } \\
\hline D-W Value & 1.212 & \multirow{2}{*}{\multicolumn{3}{|c|}{$\begin{array}{l}\text { Suspects the presence of first order autocorrelation } \\
\text { the total amount of error or variability in the dependent variable (Liquidity Position) that can't be explained } \\
\text { by the linear effect of the all independent variables }\end{array}$}} \\
\hline Error term $(\mu)$ & 0.83813 & & & \\
\hline
\end{tabular}

So, the Model is: $\mathrm{LP}=216.09+1.435 \quad$ (SPI)$1.267(\mathrm{NGB})+0.874(\mathrm{OULC})+0.838$

In the above calculated multiple regression equation, $\mathrm{a}=$ $216.09, \gamma 1=1.435, \gamma 2=-1.267$ and $\gamma 3=.0 .874$
This multiple regression equation reveals that $\hat{y}(L P)$ is dependent on DSE General share Price Index (SPI), Net Government Borrowing from Banking Sector and another independent variable named Outstanding L/C Position of 
Commercial Banks (OULC).

If the coefficients are 0 , then we may conclude that the LP will be 216.09 regardless of General share Price Index (SPI), Net Government Borrowing from Banking Sector and another Outstanding L/C Position of Commercial Banks

The coefficient $\gamma_{1=1.435}$ expresses that if DSE General share Price Index (SPI) increases by 1 percent, LP will also be increased by $1.435 \%$ Ceteris Paribas because of existing a positive relationship between the share Price Index (SPI) and LP along with the condition that the other things especially the other independent variables remain same.

The coefficient $\gamma_{2}=-1.267$ expresses that if the Net Government Borrowing from Banking Sector NGB increases by 1 percent, LP will also be decreased by $1.267 \%$ Ceteris Paribas because of prevailing negative relationship between the NGB \& LP along with the condition that the other things especially the other independent variables remain same.
The coefficient $\gamma_{3=} 0.874$ expresses that if Outstanding $\mathrm{L} / \mathrm{C}$ Position of Commercial Banks (OULC) increases by 1 percent, LP will also be increased by $0.874 \%$ Ceteris Paribas because of existing a positive relationship between the OULC and LP along with the condition that the other things especially the other independent variables remain same.

The T-test is used to determine whether each of the individual independent variable is significantly related to the dependent variable. In this model, All values are provided by the SPSS software. Using $\alpha=0.05$, we can deduce that the Pvalues of all coefficients are less than 0.05 . Hence, all parameters are statistically significant in case of individual test regarding the significance of the independent variables separately. As a corollary, three independent variables: NGB, SPI \& OULC are individually statistically significant in explaining Liquidity position (LP, Dependent variable)

Table 4. ANOVA (Analysis of Variance) for Model 01.

\begin{tabular}{lllllll}
\hline Model & & Sum of Squares & df & Mean Square & F & Sig. \\
\hline 1 & Regression & 19.270 & 3 & 6.423 & 9.144 & $.041(\mathrm{a})$ \\
& Residual & 2.107 & 3 & .702 & & \\
& Total & 21.377 & 6 & & & \\
& & & & & \\
\hline
\end{tabular}

a Predictors: (Constant), NGB, SPI, OULC

b Dependent Variable: LP

In case of ANOVA (Analysis of variance), the total sum of squares can be divided into two components: the sum of squares due to Regression (SSR) and the sum of squares due to Error (SSE) as shown below:

$\mathrm{SST}=\mathrm{SSR}+\mathrm{SSE}$.

Where,SST $=$ Total sum of squares

$\mathrm{SSR}=$ sum of squares due to regression

$\mathrm{SSE}=$ sum of errors due to error

if $\mathrm{H}_{0}$ is rejected, we have enough evidence to deduce that three of the parameters are not equal to zero and that the overall relationship between LP (Y) and other three independent variables (NGB, SPI \& OULC) is significant. However, if $\mathrm{H}_{0}$ is accepted, we don't have the sufficient evidence to deduce that a significant relationship exists between dependent and independent variables.

Before interpreting the F-test, we need to know the concept of Mean Square. In the multiple regression models, SST has (n-1) degrees of freedom, SSR has p (number of independent variables) degrees of freedom and SSE has (n-p-
1) degrees of freedom. Hence, the mean square due to regression (MSR) is SSR divided by $p$ and the mean sum of square due to error (MSE) is SSE divided by (n-p-1).

If $\mathrm{H}_{0}$ is accepted, MSR provides an unbiased estimate of $\sigma^{2}$, and the value of MSR or MSE becomes larger. To determine how large values of MSR/MSE must be to reject $\mathrm{H}_{0}$, we make use of the fact that if $\mathrm{H}_{0}$ is true and the assumptions about the multiple regression model are valid, the sampling distribution of MSR/MSE is an F-distribution with $p$ degrees of freedom in the numerator and $(n-p-1)$ in the denominator. The summary of F-test is given below:

\section{$\mathrm{F}=\mathrm{MSR} / \mathrm{MSE}=6.423 / 0.702=9.144$}

Moreover, According to P-value, it has been deduced that F-Test rejects Null Hypothesis (Ho) and expresses that there independent variables (NGB, SPI, OULC) are jointly significant on dependent variable (LP).

Model 02: $\mathrm{LP}=\mathrm{a}_{0}+\gamma_{1}(\mathrm{SPI})+\gamma_{2}(\mathrm{NGB})+\gamma_{3}(\mathrm{INV})+\mu$

The results along with explanation of this model are summarized below:

Table 5. Statistical Result of the model.

\begin{tabular}{|c|c|c|c|c|}
\hline Coefficients (Standerdized) & 20.161 & 3.360 & 1.393 & -3.236 \\
\hline S.E & 0.720 & 0.001 & 0.010 & .008 \\
\hline t-values & 27.995 & 3.987 & 4.179 & -3.471 \\
\hline p-values & 0.000 & 0.028 & 0.025 & 0.040 \\
\hline $\mathrm{R}$ & 0.950 & \multicolumn{3}{|c|}{ High degree of positive relationship } \\
\hline $\mathrm{R} 2$ & 0.903 & \multirow{2}{*}{\multicolumn{3}{|c|}{$90.3 \%$ of variability in Liquidity Position is explained by all explanatory (independent) variables }} \\
\hline Adjusted R2 & 0.805 & & & \\
\hline D-W Value & 2.344 & \multicolumn{3}{|c|}{$\begin{array}{l}\text { Suspects the presence of first order autocorrelation } \\
\text { the total amount of error or variability in the dependent variable (Liquidity Position) that can't be } \\
\text { explained by the linear effect of the all independent variables }\end{array}$} \\
\hline
\end{tabular}

So, the Estimated Model is: $\mathrm{LP}=20.161+3.360$ (SPI) +1.393 (NGB)-3.236(INV)+0.8326
In the above calculated multiple regression equation, $\mathrm{a}=$ $20.161, \gamma_{1}=1.435, \gamma_{2}=1.393$ and $\gamma_{3}=-3.236$ 
This multiple regression equation reveals that $\hat{y}(L P)$ is dependent on DSE General share Price Index (SPI), Net Government Borrowing from Banking Sector and another independent variable named Overall Investment of Commercial Banks (INV).

If the coefficients are 0 , then we may conclude that the LP will be 20.161 regardless of General share Price Index (SPI), Net Government Borrowing from Banking Sector (NGB) and Overall Investment of Commercial Banks (INV).

The coefficient $\gamma_{1=3.360}$ expresses that if DSE General share Price Index (SPI) increases by 1 percent, LP will also be increased by $3.360 \%$ Ceteris Paribas because of existing a positive relationship between the share Price Index (SPI) and LP along with the condition that the other things especially the other independent variables remain same.

The coefficient $\gamma_{2}=1.393$ expresses that if the Net Government Borrowing from Banking Sector NGB increases by 1 percent, LP will also be increased by $1.393 \%$ Ceteris Paribas because of prevailing positive relationship between the
NGB \& LP along with the condition that the other things especially the other independent variables remain same.

The coefficient $\gamma_{3}=-3.236$ expresses that if Overall Investment of Commercial Banks (INV) increases by 1 percent, LP will also be decreased by $3.236 \%$ Ceteris Paribas because of existing a inverse relationship between the INV and LP along with the condition that the other things especially the other independent variables remain same.

The T-test is used to determine whether each of the individual independent variable is significantly related to the dependent variable. In this model, All values are provided by the SPSS software. Using $\alpha=0.05$, we can deduce that the Pvalues of all coefficients are less than 0.05 . Hence, all parameters are statistically significant in case of individual test regarding the significance of the independent variables separately. As a corollary, three independent variables: NGB, SPI \& INV are individually statistically significant in explaining the Liquidity position (LP, Dependent variable).

Table 6. ANOVA(b).

\begin{tabular}{llllll}
\hline Model & & Sum of Squares & df & Mean Square & F \\
\hline 1 & Regression & 19.297 & 3 & 6.432 & 9.279 \\
& Residual & 2.080 & 3 & .693 & \\
& Total & 21.377 & 6 & & \\
\hline
\end{tabular}

a Predictors: (Constant), INV, NGB, SPI

b Dependent Variable: LP

In case of ANOVA (Analysis of variance), the total sum of squares can be divided into two components: the sum of squares due to Regression (SSR) and the sum of squares due to Error (SSE) as shown below:

$\mathrm{SST}=\mathrm{SSR}+\mathrm{SSE}$.

Where, SST $=$ Total sum of squares

$\mathrm{SSR}=$ sum of squares due to regression

$\mathrm{SSE}=$ sum of errors due to error

if $\mathrm{H}_{0}$ is rejected, we have enough evidence to deduce that three of the parameters are not equal to zero and that the overall relationship between LP $(\hat{Y})$ and other three independent variables (NGB, SPI \& INV) is significant. However, if $\mathrm{H}_{0}$ is accepted, we don't have the sufficient evidence to deduce that a significant relationship exists between dependent and independent variables.

Before interpreting the F-test, we need to know the concept of Mean Square. In the multiple regression models, SST has (n-1) degrees of freedom, SSR has $p$ (number of independent variables) degrees of freedom and SSE has (n-p-
1) degrees of freedom. Hence, the mean square due to regression (MSR) is SSR divided by $\mathrm{p}$ and the mean sum of square due to error (MSE) is SSE divided by (n-p-1).

If $\mathrm{H}_{0}$ is accepted, MSR provides an unbiased estimate of $\sigma^{2}$, and the value of MSR or MSE becomes larger. To determine how large values of MSR/MSE must be to reject $\mathrm{H}_{0}$, we make use of the fact that if $\mathrm{H}_{0}$ is true and the assumptions about the multiple regression model are valid, the sampling distribution of MSR/MSE is an F-distribution with $p$ degrees of freedom in the numerator and (n-p-1) in the denominator. The summary of F-test is given below:

$$
\mathrm{F}=\mathrm{MSR} / \mathrm{MSE}=6.423 / 0.693=9.279
$$

Moreover, According to P-value, it has been deduced that F-Test rejects Null Hypothesis (Ho) and expresses that there independent variables (NGB, SPI, INV) are jointly significant in explaining dependent variable (LP).

Model 03: $\mathrm{LP}=\mathrm{a}_{\mathrm{o}}+\gamma_{1}(\mathrm{OULC})+\gamma_{2}(\mathrm{NGB})+\gamma_{3}(\mathrm{CL})+\mu$

The results along with explanation of this model are summarized below:

Table 7. Statistical Result of the model.

\begin{tabular}{|c|c|c|c|c|}
\hline Coefficients (Standerdized) & 13.913 & -2.211 & 0.661 & 2.333 \\
\hline S.E & 2.093 & 0.000 & 0.007 & 0.029 \\
\hline t-values & 6.647 & -3.649 & 2.919 & 4.041 \\
\hline p-values & 0.007 & 0.036 & 0.062 & 0.027 \\
\hline $\mathrm{R}$ & 0.942 & \multicolumn{3}{|c|}{ High degree of positive relationship } \\
\hline $\mathrm{R} 2$ & 0.887 & \multirow{2}{*}{\multicolumn{3}{|c|}{$88.7 \%$ of variability in Liquidity Position is explained by all explanatory (independent) variables }} \\
\hline Adjusted R2 & 0.773 & & & \\
\hline D-W Value & 2.557 & \multirow{2}{*}{\multicolumn{3}{|c|}{$\begin{array}{l}\text { Suspects the presence of first order autocorrelation } \\
\text { the total amount of error or variability in the dependent variable (Liquidity Position) that can't be } \\
\text { explained by the linear effect of the all independent variables }\end{array}$}} \\
\hline Error term $(\mu)$ & 0.8988 & & & \\
\hline
\end{tabular}


So, the Model is: $L P=13.913-2.211 \quad$ (OULC) +0.661 $(\mathrm{NGB})+2.33(\mathrm{CL})+0.8988$

In the above calculated multiple regression equation, $\mathrm{a}=$ $13.913, \gamma_{1}=-2.211, \gamma_{2}=0.661$ and $\gamma_{3}=2.33$

This multiple regression equation reveals that $\hat{y}(L P)$ is dependent on Outstanding L/C Position of Commercial Banks (OULC), Net Government Borrowing from Banking Sector (NGB) and another independent variable named Overall Classified Loan in Commercial Banks (CL).

If the coefficients are 0 , then we may conclude that the LP will be 13.913 regardless of Outstanding L/C Position of Commercial Banks (OULC), Net Government Borrowing from Banking Sector (NGB) and Overall Classified Loan in Commercial Banks (CL).

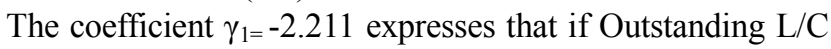
Position of Commercial Banks (OULC) increases by 1 percent, LP will also be decreased by $2.211 \%$ Ceteris Paribas because of existing a negative relationship between OULC and LP along with the condition that the other things especially the other independent variables remain same.

The coefficient $\gamma_{2}=0.661$ expresses that if the Net Government Borrowing from Banking Sector NGB increases by 1 percent, LP will also be increased by $0.661 \%$ Ceteris Paribas because of prevailing positive relationship between the NGB \& LP along with the condition that the other things especially the other independent variables remain same.

The coefficient $\gamma_{3}=2.33$ expresses that if Overall Classified Loan in Commercial Banks (CL) increases by 1 percent, LP will also be increased by $2.33 \%$ Ceteris Paribas because of existing a positive relationship between the CL and LP along with the condition that the other things especially the other independent variables remain same.

The T-test is used to determine whether each of the individual independent variable is significantly related to the dependent variable. In this model, all values are provided by the SPSS software. Using $\alpha=0.05$, we can deduce that the Pvalues of all coefficients are less than 0.05 . Hence, all parameters except Government Borrowing (NGB) are statistically significant in case of individual test regarding the significance of the independent variables separately. As a corollary, two independent variables OULC \& CL are individually statistically significant in explaining the Liquidity position (LP, Dependent variable).

Table 8. ANOVA(b).

\begin{tabular}{lllllll}
\hline Model & & Sum of Squares & df & Mean Square & F & Sig. \\
\hline 1 & Regression & 18.954 & 3 & 6.318 & 7.820 & $.063(\mathrm{a})$ \\
& Residual & 2.424 & 3 & .808 & & \\
& Total & 21.377 & 6 & & & \\
\hline
\end{tabular}

a Predictors: (Constant), CL, NGB, OULC

b Dependent Variable: LP

In case of ANOVA (Analysis of variance), the total sum of squares can be divided into two components: the sum of squares due to Regression (SSR) and the sum of squares due to Error (SSE) as shown below:

$\mathrm{SST}=\mathrm{SSR}+\mathrm{SSE}$.

Where, SST $=$ Total sum of squares

$\mathrm{SSR}=$ sum of squares due to regression

$\mathrm{SSE}=$ sum of errors due to error

if $\mathrm{H}_{0}$ is rejected, we have enough evidence to deduce that three of the parameters are not equal to zero and that the overall relationship between LP ( $\hat{Y})$ and other three independent variables (CL, NGB, OULC) is significant. However, if $\mathrm{H}_{0}$ is accepted, we don't have the sufficient evidence to deduce that a significant relationship exists between dependent and independent variables.

If $\mathrm{H}_{0}$ is accepted, MSR provides an unbiased estimate of $\sigma^{2}$, and the value of MSR or MSE becomes larger. To determine how large values of MSR/MSE must be to reject $\mathrm{H}_{0}$, we make use of the fact that if $\mathrm{H}_{0}$ is true and the assumptions about the multiple regression model are valid, the sampling distribution of MSR/MSE is an F-distribution with $p$ degrees of freedom in the numerator and (n-p-1) in the denominator. The summary of F-test is given below:

$\mathrm{F}=\mathrm{MSR} / \mathrm{MSE}=6.423 / 0.693=9.279$

Moreover, According to P-value, it has been deduced that FTest accepts Null Hypothesis (Ho) and expresses that there independent variables (CL, NGB, OULC) are jointly insignificant in explaining dependent variable (LP).

Model 04: $\mathrm{LP}=\mathrm{a}_{0}+\gamma_{1}(\mathrm{NGB})+\gamma_{2}(\mathrm{OULC})+\gamma_{3}\left(\mathrm{M}_{2}\right)+\mu$

The results along with explanation of this model are summarized below:

Table 9. Statistical Result of the model.

\begin{tabular}{|c|c|c|c|c|}
\hline Coefficients (Standerdized) & 19.217 & 0.522 & -1.774 & 1.979 \\
\hline S.E & 1.148 & 0.007 & 2.447 & 0.001 \\
\hline t-values & 16.735 & 2.147 & -4.154 & 3.629 \\
\hline p-values & 0.000 & 0.121 & 0.041 & 0.036 \\
\hline $\mathrm{R}$ & 0.930 & \multicolumn{3}{|c|}{ High degree of positive relationship } \\
\hline R2 & 0.864 & \multicolumn{3}{|c|}{$86.4 \%$ of variability in Liquidity Position is explained by all explanatory (independent) variables } \\
\hline Adjusted R2 & 0.729 & \multirow{3}{*}{\multicolumn{3}{|c|}{$\begin{array}{l}\text { Suspects No presence of first order autocorrelation } \\
\text { the total amount of error or variability in the dependent variable (Liquidity Position) that can't } \\
\text { be explained by the linear effect of the all independent variables }\end{array}$}} \\
\hline D-W Value & $1.99 \sim 2$ & & & \\
\hline Error Term $(\mu)$ & 0.9828 & & & \\
\hline
\end{tabular}


So, the Model is: $\mathrm{LP}=19.217+0.522 \quad(\mathrm{NGB})-1.774$ $\left(\right.$ OULC) $+1.979\left(\mathrm{M}_{2}\right)+0.983$

In the above calculated multiple regression equation, $\mathrm{a}=$ $19.217, \gamma_{1}=0.522, \gamma_{2}=-1.774$ and $\gamma_{3=} 1.979$

This multiple regression equation reveals that $\hat{y}(\mathrm{LP})$ is dependent on Outstanding L/C Position of Commercial Banks (OULC), Net Government Borrowing from Banking Sector (NGB) and another independent variable named $\mathrm{M}_{2}$ $\left(\mathrm{M}_{1}+\right.$ Time Deposit)

If the coefficients are 0 , then we may conclude that the LP will be 19.217 regardless of Outstanding L/C Position of Commercial Banks (OULC), Net Government Borrowing from Banking Sector (NGB) and Overall $\mathrm{M}_{2}\left(\mathrm{M}_{1}+\right.$ Time Deposit).

The coefficient $\gamma_{1=} 0.522$ expresses that if Net Government Borrowing from Banking Sector (NGB) increases by 1 percent, LP will also be increased by $0.522 \%$ Ceteris Paribas because of existing a positive relationship between NGB and LP along with the condition that the other things especially the other independent variables remain same.

The coefficient $\gamma_{2}=-1.774$ expresses that if the Outstanding L/C Position of Commercial Banks (OULC) increases by 1 percent, LP will also be decreased by $1.774 \%$ Ceteris Paribas because of prevailing inverse relationship between the OULC \& LP along with the condition that the other things especially the other independent variables remain same.

The coefficient $\gamma_{3=} 1.979$ expresses that if Overall $\mathrm{M}_{2}$ $\left(\mathrm{M}_{1}+\right.$ Time Deposit) increases by 1 percent, LP will also be increased by $1.979 \%$ Ceteris Paribas because of existing a positive relationship between the $\mathrm{M}_{2}\left(\mathrm{M}_{1}+\right.$ Time Deposit) and LP along with the condition that the other things especially the other independent variables remain same.

The T-test is used to determine whether each of the individual independent variable is significantly related to the dependent variable. In this model, all values are provided by the SPSS software. Using $\alpha=0.05$, we can deduce that the Pvalues of all coefficients are less than 0.05 . Hence, all parameters are statistically significant except coefficient $\gamma_{1}$ for Net Government Borrowing from Banking Sector (NGB) in case of individual test regarding the significance of the independent variables separately. As a corollary, two independent variables: OULC \& $\mathrm{M}_{2}\left(\mathrm{M}_{1}+\right.$ Time Deposit $)$ are individually statistically significant in explaining the Liquidity position (LP, Dependent variable).

Table 10. ANOVA(b).

\begin{tabular}{lllllll}
\hline Model & & Sum of Squares & df & Mean Square & F & Sig. \\
\hline 1 & Regression & 18.480 & 3 & 6.160 & 6.377 & $.081(\mathrm{a})$ \\
& Residual & 2.898 & 3 & .966 & & \\
& Total & 21.377 & 6 & & & \\
\hline
\end{tabular}

a Predictors: (Constant), M2, NGB, OULC

b Dependent Variable: LP

In case of ANOVA (Analysis of variance), the total sum of squares can be divided into two components: the sum of squares due to Regression (SSR) and the sum of squares due to Error (SSE) as shown below:

$\mathrm{SST}=\mathrm{SSR}+\mathrm{SSE}$.

Where,SST $=$ Total sum of squares

$\mathrm{SSR}=$ sum of squares due to regression

$\mathrm{SSE}=$ sum of errors due to error

if $\mathrm{H}_{0}$ is rejected, we have enough evidence to deduce that three of the parameters are not equal to zero and that the overall relationship between LP $(\hat{Y})$ and other three independent variables (NGB, OULC \& M2) is significant. However, if $\mathrm{H}_{0}$ is accepted, we don't have the sufficient evidence to deduce that a significant relationship exists between dependent and independent variables.

If $\mathrm{H}_{0}$ is accepted, MSR provides an unbiased estimate of $\sigma^{2}$, and the value of MSR or MSE becomes larger. To determine how large values of MSR/MSE must be to reject $\mathrm{H}_{0}$, we make use of the fact that if $\mathrm{H}_{0}$ is true and the assumptions about the multiple regression model are valid, the sampling distribution of MSR/MSE is an F-distribution with $p$ degrees of freedom in the numerator and (n-p-1) in the denominator. The summary of F-test is given below:

$\mathrm{F}=\mathrm{MSR} / \mathrm{MSE}=6.160 / 0.966=6.377$

Moreover, According to P-value, it has been deduced that F-Test accepts Null Hypothesis (Ho) and expresses that there independent variables $\left(\mathrm{M}_{2}, \mathrm{NGB}\right.$, OULC) are jointly insignificant in explaining dependent variable (LP).

\section{Findings}

The major findings after analyzing the above qualitative and quantitative evaluations are revealed below:

- Net Government Borrowing (NGB) is not individually significant in influencing the overall liquidity position of commercial Banks in Bangladesh.

- Rescheduling of short term loan to long term loan and the rules thereof exert major influence in deteriorating the overall liquidity position of commercial banks.

- The abuse of loan against trust receipt (LTR) and loan against imported merchandise (LIM) causes rescheduling of these loans that accelerate the further deterioration of liquidity position of commercial banks in Bangladesh.

- Currency devaluation against dollar due to international increase of petroleum price as well as reduction in foreign aid or grants also accelerate the liquidity crisis in recent years.

- The more NPL to Total Loan ratio also cognizant as Infection ratio is, the more deteriorating the liquidity position is.

- Government borrowing along with all explanatory 
variables is jointly statistically significant in influencing the overall liquidity position of all commercial Banks in Bangladesh although NGB is not individually significant in influencing liquidity position.

- In each of the Econometric models mentioned in this paper, there is a high degree of positive relationship between liquidity position and all other explanatory variables.

- All explanatory variables mentioned in each of the models developed in this paper have explained significant proportions of recent Liquidity position of commercial banks in Bangladesh.

\section{Conclusions}

One of the most crucial undertakings in the management of any financial institution is ensuring adequate liquidity at all times, no matter what emergencies may appear. A financial firm is considered to be liquid if it has easy access to immediately spendable funds at reasonable cost at precisely the time those funds are needed. Interest rates are so important in controlling liquidity that these rates really dictate how expensive it is to borrow. Low interest rates mean credit is cheap, so businesses and investors are more likely to borrow. However, liquidity crisis refers to drying up of liquidity, which could reflect a fall in asset prices below their long run fundamental price; or deterioration in external financing conditions; or a reduction in the number of market participants or simply difficulty in trading assets. A liquidity crisis is usually unpredictable and can be due to either a lack of confidence in the specific bank, or some unexpected need for cash. Although Net Government Borrowing from banking sector affects the liquidity position of commercial banks through creating Crowding-out effect for private investors, this paper has concluded that the models mentioned in this study reveal that Net Government Borrowing is not individually significant in explaining Liquidity position of commercial banks rather This Net government borrowing along with other variables is jointly significant in explaining liquidity position.

\section{References}

[1] BIS (2009). International framework for liquidity risk measurement, standards and monitoring. Basel: Bank for International Settlements.
[2] B. Ozdincer, C. Ozyildirim, "Determining the Factors of Bank Performance with a Focus on Risk and Technical Efficiency," in Proceedings from 2nd WSEAS International Conference on Management, Marketing and Finances (MMF' 08), Harvard, 2008, pp. 31-39.

[3] BESSIS, J. (2009). Risk Management in Banking. Chichester: John Wiley \& Sons.

[4] Heller, D.; Lengwiller, Y. (2003) Payment obligations, reserves requirements, and the demand for central bank balance, Journal of Monetary Economics, 50, 419-432.

[5] International Monetary Fund (2010) Cape Verde: Article IV Consultation and Request for a 15- Month Policy Support Instrument - Staff Report, December 2010 IMF Country Report 10/349. (http://www.imf.org/external/pubs/ft/scr/2010/cr10349.pdf).

[6] M. K. Brunnermeier, "Deciphering the Liquidity and Credit Crunch 2007-2008," Journal of Economic Perspectives, vol. 23, no. 1, pp. 77- 100, 2009.

[7] M. Drehmann, K. Nikolau, "Funding Liquidity Risk. Definition and Measurement. "ECB Working Paper, no. 1024, 2009.

[8] MOORE, W. (2010). How do financial crises affect commercial bank liquidity? Evidence from Latin America and the Caribbean. MPRA Paper 2010-21473. Munich: Munich Personal RePEc Archive.

[9] O. Aspachs, E. Nier, M. Tiesset, "Liquidity, Banking Regulation and the Macroeconomy. Evidence on bank liquidity holdings from a panel of UK-resident banks.," Bank of England Working Paper, 2005.

[10] Principles for Sound Liquidity Risk Management and Supervision. Bank for International Settlements, 2008.

[11] PRAET, P. - HERZBERG, V. (2008). Market liquidity and banking liquidity: linkages, vulnerabilities and the role of disclosure. In Banque de France Financial stability Review. France: Banque de France, pp. 95-109.

[12] RAUCH, C. - STEFFEN, S. - HACKETHAL, A. - TYRELL, M. (2010). Determinants of Bank Liquidity Creation. Available http://papers.ssrn.com/sol3/papers.cfm?abstract id=1343595

[13] RYCHTÁRIK, Š. (2009). Liquidity Scenario Analysis in the Luxembourg Banking Sector. BCDL Working Paper 2009-41. Luxembourg: Banque Centrale du Luxembourg.

[14] Saxegaard, Magnus (2006) Excess Liquidity and the Effectiveness of Monetary Policy: Evidence from SubSaharan Africa, International Monetary Fund, Working Paper 06/115. 